\title{
Effect of Ethanolic Leaves Extract of Peperomia pellucida (L) Kunth as Antimalarial and Antioxidant
}

Efek Ekstrak Etanol Daun Suruhan Peperomia pellucida (L) Kunth sebagai Antimalaria and Antioksidan

\author{
Nanang Yunarto ${ }^{1 *}$, Hanief Mulia Ar Rossyid ${ }^{2}$, and Lisa Andriani Lienggonegoro ${ }^{1}$ \\ ${ }_{1 *}$ Pusat Penelitian dan Pengembangan Biomedis dan Teknologi Dasar Kesehatan,Badan Penelitian dan \\ Pengembangan Kesehatan, Kementerian Kesehatan RI, Jl. Percetakan Negara No 23 Jakarta, Indonesia \\ 10560 \\ ${ }^{2}$ Jurusan Farmasi, Universitas Jenderal Soedirman, Jl. Dr Soeparno Karangwangkal, Purwokerto, Indonesia \\ 53122 \\ *Korespondensi Penulis: nanang.safactory@gmail.com
}

Submitted: 19-07-2018, Revised: 25-08-2018, Accepted: 03-09-2018

DOI: http://dx.doi.org/10.22435/mpk.v28i2.132

\begin{abstract}
Abstrak
Pada infeksi malaria, parasit Plasmodium akan memecah hemoglobin dalam sel darah merah inang menjadi asam amino dan hem bebas yang bersifat toksik. Plasmodium juga mampu merubah hem bebas menjadi hemozoin yang tidak toksik melalui proses polimerisasi. Infeksi malaria disisi lain juga memicu terbentuknya radikal bebas yang berdampak pada patofisiologi malaria. Daun suruhan (Peperomia pellucida (L) Kunth) sejak lama digunakan sebagai antimalaria dan diketahui memiliki kandungan flavonoid yang besar yang berfungsi sebagai antioksidan. Penelitian ini bertujuan untuk menguji efek ekstrak etanol daun suruhan sebagai antimalaria dan antioksidan secara in vitro. Pada penelitian ini dilakukan ekstraksi daun suruhan, uji aktivitas penghambatan polimerisasi hem dan uji aktivitas antioksidan. Secara organoleptik, ekstrak daun suruhan yang didapat berbentuk ekstrak kering, berwarna hijau kehitaman, memiliki rasa pahit dengan bau khas daun suruhan. Yield ekstrak yang diperoleh sebesar 18,28\%, kadar air 7,73\%, susut pengeringan $9,16 \%$ dan kadar abu total $0,46 \%$. Nilai IC 50 aktivitas penghambatan polimerisasi hem ekstrak etanol daun suruhan adalah $0,93 \mathrm{mg} / \mathrm{mL}$, lebih kecil dibanding dengan klorokuin yang mencapai $1,48 \mathrm{mg} / \mathrm{mL}$. Sedangkan nilai IC 50 aktivitas antioksidan ekstrak etanol daun suruhan adalah $32,94 \mathrm{mg} / \mathrm{mL}$ dibandingkan dengan Vitamin C sebesar $4 \mathrm{mg} / \mathrm{mL}$. Berdasarkan hasil penelitian dapat disimpulkan bahwa ekstrak etanol daun suruhan memiliki aktivitas penghambatan polimerisasi hem dan aktivitas antioksidan sehingga memiliki potensi sebagai obat antimalaria.
\end{abstract}

Kata kunci: Peperomia pellucida, anti malaria, antioksidan, polimerisasi hem

\begin{abstract}
In malaria infection, the Plasmodium parasites break down hemoglobin in the host's red blood cells into toxic free heme and amino acids. Plasmodium is also capable of converting free heme to non-toxic hemozoin through a polymerization process. Malaria infection, on the other hand, also triggers the formation of free radicals that affect the pathophysiology of malaria. Suruhan leaf (Peperomia pellucida (L.) Kunth) has long been used as an antimalarial and is known to contain large flavonoids that function as antioxidants. This study aimed to examine antimalarial and antioxidant activity of ethanol extract of suruhan leaves in vitro. In this study, leaf extraction, inhibitory activity of heme polymerization assay, and antioxidant activity assay were performed. Organoleptically, leaf extract obtained in the form of dry blackish green coloured extracts with a bitter taste and the typical scent of suruhan leaves. The yield of the extract obtained was $18.28 \%$, water content was $7.73 \%$, drying shrinkage was $9.16 \%$, and total ash content was $0.46 \%$. The IC 50 value of inhibition activity of heme polymerization of ethanol extract of the suruhan leaf was $0.93 \mathrm{mg} / \mathrm{mL}$, smaller compared to chloroquine $(1.48 \mathrm{mg} / \mathrm{mL})$ while the value of $\mathrm{IC}_{50}$. The antioxidant activity of ethanol extract
\end{abstract}


of suruhan leaf was $32.94 \mu \mathrm{g} / \mathrm{mL}$ compared to Vitamin C of $4 \mu \mathrm{g} / \mathrm{mL}$. In conclusion, ethanolic extract of suruhan leaf has inhibitory activity of heme polymerization and antioxidant activity so that it has potentiality as antimalarial drugs.

Keywords: Peperomia pellucida, anti malarial, antioxidant, heme polymerization

\section{INTRODUCTION}

Malaria is an infectious disease caused by Plasmodium, a genus of parasitic protozoans. Malaria is transmitted through female Anopheles mosquito bite containing Plasmodium parasites. Based on World Malaria Report 2016, malaria has been spread into 92 nations. Malaria is one of the leading causes of death globally with a half of world population having the infection risk. 216 malaria cases were reported all over the world in 2015 and more than 426 people died. ${ }^{1}$ Malaria is one of the noteworthy diseases which need more serious treatment in Indonesia. The Annual Parasite Incidence (API) national data is 0.85 in 2015, but the API of endemic areas, such as Papua, West Papua, East Nusa Tenggara (NTT), and Maluku are still high. This becomes a hard challenge for the government in malaria elimination program. ${ }^{2}$

When malaria infection occurs, Plasmodium invades the host's red blood cells and degrades hemoglobin in its food vacuole to gain essential substances to support the parasite life cycle. Hemoglobin degradation produces a disposal product namely the free heme that is toxic for the host or parasites. For its survival, plasmodium converts the free heme to nontoxic hemozoin. ${ }^{3}$

Plasmodium infection elicits the activation of immune system and reactive oxygen species (ROS) formation which induce destruction and oxidative damage. ${ }^{4}$ Naturally, a human body has several mechanisms to minimize the negative effectsof ROS on cells. One of body defense mechanisms is antioxidant production. Preventive antioxidants such as catalase, glutathion peroxidases, EDTA, and vitamin C inhibit initial production of free radicals including ROS, whereas chain-breaking antioxidants such as superoxide dismutases, uric acid, and vitamin E inhibit damages due to ROS. ${ }^{5}$ However, acute malaria infection decreases antioxidant enzymes amount, activity, and other antioxidants, and increases free radicals resulted in the weakening of immune system. ${ }^{6}$

Free radicals play a role in pathogenesis of many human diseases, including atherosclerosis, cancer, diabetes mellitus, liver damage, skin tissue damage, inflammation, coronary heart disease and arthritis. ${ }^{7}$ The use of synthetic antioxidants to prevent free radical damage has been reported to inflict toxic effects, therefore, it is necessary to explore new sources of antioxidants from nature. ${ }^{8}$ One of natural ingredients reported to have high antioxidant activity is flavonoid that can be found as secondary metabolite compounds from plants and fungi. ${ }^{9}$

Some ethnomedicine plants have been used as antimalarials such as Artemisia annua, Ceiba petandra, Eurycoma apiculata and Citrus mitis. One of the new plants that has the potential as an antimalarial drug and is widely grown in Indonesia is suruhan leaf (Peperomia pellucida (L) Kunth). ${ }^{10,11}$ The secondary metabolites in suruhan is flavonoid. The high flavonoid content in suruhan plant has potential effect as antioxidant. ${ }^{12}$ Antioxidant compounds in flavonoid play a role to minimize the negative effects of ROS due to malaria infection to cells. This study aimed to examine antimalarial and antioxidant activity of ethanol extract of suruhan leaves in vitro by heme polymerization and free radical scavenger.

\section{METHOD}

This study was a laboratory experimental study, conducted in Universitas Jenderal Soedirman, Purwokerto and the Centre for Biomedical and Basic Technology of Health, Jakarta.

Materials used in this study were suruhan leaves, originated from Banyumas, 2,2-diphenyl1-picrylhydrazyl/DPPH (Sigma), ascorbic acid (Sigma), hematin (Sigma), glacial acetic acid (Merck), DMSO (Merck), NaOH (Merck, 99\%), methanol (Merck, for analysis 99\%), technical ethanol $70 \%$.

The working procedures started with extraction. Fresh suruhan leaves were dried directly under sunlight, covered with black fabric, then dried in the oven at $50^{\circ} \mathrm{C}$ until the water content of the simplicia was under $10 \%$. The preparation of the extract was done by inserting 500 grams of simplicia dry powder into macerator, afterwards, 10 parts $(5000 \mathrm{~mL})$ of ethanol $70 \%$ was then added. The simplicia was immersed for 6 hours while stirred with shaker, then settled for 18 hours. Afterwards, the maserate was separated by 
filtration using filter papers. The filtration process was repeated twice. Next, the maserate was concentrated using rotavapor (Buchi) until it was viscous to minimize water content, the evaporation process was continued in waterbath and vacuum oven. The extracts obtained were characterized by organoleptic examination, water content, drying rate, and ash content. ${ }^{13}$

In vitro antimalarial activity assay was carried out incompliance with the inhibition method of heme polymerization. ${ }^{14} 100 \mu \mathrm{L}$ of 1 $\mathrm{mM}$ hematin solution in $0.2 \mathrm{M} \mathrm{NaOH}$ was put into Eppendorf tube, afterwards, $50 \mu \mathrm{L}$ of material assay with various concentration level was added in several concentration levels, starting from 0.25 $\mathrm{mg} / \mathrm{mL}, 0.5 \mathrm{mg} / \mathrm{mL}, 1 \mathrm{mg} / \mathrm{mL}, 2 \mathrm{mg} / \mathrm{mL}$, and 4 $\mathrm{mg} / \mathrm{mL}$. This step was then replicated three times for each concentration level. Next, DMSO was added in the dissolution process to facilitate the preparation of extract and chloroquin, until the DMSO concentration reached $10 \% .50 \mu \mathrm{L}$ glacial acetic acid solution ( $\mathrm{pH}$ 2.6) was then added into Eppendorf tube containing hematin solution and sample test to initiate heme polymerization reaction, then incubated at $37^{\circ} \mathrm{C}$ for 24 hours. Chloroquine diphosphate acted as positive control whereas aquadest and DMSO 10\% acted as negative control. After the incubation was finished, the Eppendorf tubes were centrifuged at $8000 \mathrm{rpm}$ for 10 minutes. The supernatants were discarded, then the pellets were washed four times with $200 \mu \mathrm{L}$ DMSO and $8000 \mathrm{rpm}$ centrifugation for 10 minutes. The pellets were dissolved in $200 \mu \mathrm{L} 0.1 \mathrm{M} \mathrm{NaOH}$ and every $100 \mu \mathrm{L}$ solution obtained were put into 96-well microplate and read at $405 \mathrm{~nm}$ with microplate reader (Thermo Scientific Multiscan EX). The value of heme polymerization inhibitory activity is expressed in $\mathrm{IC}_{50}$, the concentration level needed to inhibit heme polymerization until $50 \%$, compared to negative control. The standard curve was made by making hematin concentration series (which was dissolved in $0.2 \mathrm{M} \mathrm{NaOH}$ ). The concentration series were : $250 ; 125 ; 62.5 ; 31.25 ; 15.6 ; 7.8$; and $3.9 \mathrm{mM}$. The inhibition procentage was calculated based on equation (1) and $\mathrm{IC}_{50}$ (concentration compounds that have the ability to inhibit heme polymerization until $50 \%$ ), calculated using linier regression analysis. ${ }^{15}$

$\%$ Inhibition $=(\mathrm{A}-\mathrm{B}) / \mathrm{A} \times 100 \% \ldots .(1)$

Annotation :

$\mathrm{A}=$ hematin concentration of negative control
$\mathrm{B}=$ hematin concentration of sample assay

The antioxidant activity was examined using radical scavenging method using DPPH radical. ${ }^{16,17} 0.1 \mathrm{mM}$ solution of DPPH in methanol was prepared and $1 \mathrm{ml}$ of this solution was added to $3 \mathrm{ml}$ of various concentrations $(5,10,25,50$, $100 \mu \mathrm{g} / \mathrm{mL}$ ) of sample dissolved in methanol to be tested, ascorbic acid (vitamin $\mathrm{C}$ ) as a reference standard of $0.5,1,2,4$ and $8 \mu \mathrm{g} / \mathrm{mL}$. The difference in serial concentration between sample and vitamin $\mathrm{C}$, because activity of vitamin $\mathrm{C}$ with a small concentration can be measured. All test solutions, control and vitamin were incubated at $37^{\circ} \mathrm{C}$ then pipetted to spectrophotometry cuvette and incubated at $37^{\circ} \mathrm{C}$ for 30 minutes. Blank solution was prepared from ethanol and ascorbic acid used as reference blank. The absorbance was measured using UV-Vis spectrophotometer (Spectroquant Prove 300) at $515 \mathrm{~nm}$ wavelength. The antioxidant activity was obtained using equation (2) and $\mathrm{IC}_{50}$ value which indicated test solution concentration able to inhibit $50 \%$ oxidation process obtained by making a linear curve between test solution concentration (x-axis) and \% antioxidant activity (y-axis).

$\%$ Inhibition $=(\mathrm{A}-\mathrm{B}) / \mathrm{A} \times 100 \% \ldots$ (2)

Annotation:

$\mathrm{A}=$ blank absorbance

$\mathrm{B}=$ test solution absorbance

\section{RESULT}

The extraction of suruhan leaves was carried out by maceration aimed to obtain optimum yield. Organoleptically, leaf extract obtained in the form of dry blackish green coloured extracts with a bitter taste and the typical scent of suruhan leaves. The yield of the extract obtained was $18.28 \%$, water content was $7.73 \%$, drying shrinkage was $9.16 \%$, and total ash content was $0.46 \%$. The result of extract characterization test is shown in Table 1.

The result of antimalarial test using inhibition heme polymerization method came with $\mathrm{IC}_{50}$ value of ethanol extract of suruhan leaves 0.93 $\mathrm{mg} / \mathrm{mL}$ is shown in Table 2. This value is smaller than chloroquine used as comparator $\left(\mathrm{IC}_{50}\right.$ of 1.48 $\mathrm{mg} / \mathrm{mL}$ ). The smaller the $\mathrm{IC}_{50}$ value means the higher the antimalarial activity. These data show that antimalarial activity of suruhan leaves extract is very strong.

The result of antioxidant activity assay indicated that ethanol extract of suruhan leaves 
extract has antioxidant activity to inhibit $50 \%$ $\left(\mathrm{IC}_{50}\right)$ of free radicals formation is shown in Table 3. $\mathrm{IC}_{50}$ of antioxidant activity of suruhan leaves extract in the assay was $32.94 \mu \mathrm{g} / \mathrm{mL}$ while $\mathrm{IC}_{50}$ of vitamin $\mathrm{C}$ was $4.0 \mu \mathrm{g} / \mathrm{mL}$ (Table 3). The strength of antioxidant activity can be classified into very active, if it had $\mathrm{IC}_{50}<10 \mu \mathrm{g} / \mathrm{mL}$, active with $\mathrm{IC}_{50}$ $10-100 \mu \mathrm{g} / \mathrm{mL}$, and inactive if $\mathrm{IC}_{50}>100 \mu \mathrm{g} / \mathrm{mL} .16$ The antioxidant activity of suruhan leaves extract is included in active group, but it is still under vitamin $\mathrm{C}$ as positive control.

Table 1. Result of Characterization of Ethanol Extract from Suruhan Leaves

\begin{tabular}{cc}
\hline Characterization & Result \\
\hline Form & Dry extract \\
Colour & Blackish green \\
Odor & Typical \\
Taste & Bitter \\
Yield & $18.28 \%$ \\
Water content & $7.73 \%$ \\
Drying shrinkage & $9.16 \%$ \\
Total ash content & $0.46 \%$ \\
\hline
\end{tabular}

Table 2. IC50 of Heme Polymerization Inhibitory Activity of Ethanol Extract of Suruhan Leaves

\begin{tabular}{cccc}
\hline Sample & Concentration $(\mathbf{m g} / \mathbf{m L})$ & Inhibition $(\%)$ & IC50 $(\mathbf{m g} / \mathbf{m L})$ \\
\hline Extract & 0.25 & $40.60 \pm 0.07$ & 0.93 \\
& 0.50 & $42.84 \pm 0.15$ & $55.07 \pm 0.07$ \\
1.00 & $63.64 \pm 0.15$ & $70.69 \pm 0.07$ \\
& 2.00 & & 1.48 \\
Chloroquine & 4.00 & $14.03 \pm 0.17$ \\
& 0.25 & $21.60 \pm 0.17$ \\
& 0.50 & $33.52 \pm 0.08$ \\
& 1.00 & $41.72 \pm 0.08$ \\
& 2.00 & $50.53 \pm 0.08$ & \\
\hline
\end{tabular}

Tabel 3. IC50 of Antioxidant Activity of Ethanol Extract of Suruhan Leaves

\begin{tabular}{|c|c|c|c|}
\hline Sample code & Concentration $(\mu \mathrm{g} / \mathrm{mL})$ & Inhibition (\%) & $\mathrm{IC}_{50}(\mu \mathrm{g} / \mathrm{mL})$ \\
\hline \multirow[t]{5}{*}{ Extract } & 5 & $12,36 \pm 0,34$ & \\
\hline & 10 & $25,24 \pm 0,17$ & \\
\hline & 25 & $53,72 \pm 0,08$ & 32.94 \\
\hline & 50 & $86,63 \pm 0,17$ & \\
\hline & 100 & $92,96 \pm 0,35$ & \\
\hline \multirow[t]{5}{*}{ Vitamin C } & 0,5 & $9,32 \pm 0,05$ & \\
\hline & 1 & $17,86 \pm 0,06$ & \\
\hline & 2 & $32,45 \pm 0,06$ & 4.00 \\
\hline & 4 & $56,28 \pm 0,05$ & \\
\hline & 8 & $87,67 \pm 0,12$ & \\
\hline
\end{tabular}




\section{DISCUSSION}

\section{Extraction}

Extraction process is aimed at gaining secondary metabolites instead of primary metabolites. The secondary metabolite compounds were produced by extraction. The use of $70 \%$ ethanol solution aimed to attract flavonoid compound contained in the leaf in the form of polar glycoside flavonoid. In addition, ethanol is volatile so the drying process of the extract is faster. Organoleptically, suruhan leaves extract obtained was in the form of dry blackish green coloured extracts with a bitter taste and the typical scent of suruhan leaf. The determination of organoleptic parameters aimed to give the initial introduction of the extract objectively and simply using the five senses. The obtained yield extract was $18.28 \%$. The result is higher compared to that of another study by Irsyad et al. ${ }^{18}$ The difference is possible due to the difference in the plant growth location that may affect the secondary metabolites content.

The determination of water content is aimed at examining the water content in suruhan leaf extract. The extract obtained had $7.73 \%$ water content, which means it meets the requirements of Farmakope Herbal Indonesia, which is below $10 \%$. The lower the water content in the drug material means the lower the risk of microbial growth, fungi, or insect damage. The determination of drying shrinkage aimed to discover how much compounds (water and volatile compounds) were lost during the heating at $105^{\circ} \mathrm{C}$. The result of suruhan leaves extract drying shrinkage was $9.16 \%$. The value of drying shrinkage was higher than the water content, this result explained that besides water, there were volatile compounds in the extract. ${ }^{13}$

The determination of ash content provided an overview of internal and external mineral content from the initial process until the extract formed. The principle was heating the extract until the organic compounds and their derivatives were destructed and evaporated, and left behind only inorganic and mineral elements. The total ash content obtained from the extract was $0.46 \%$, which met the requirement in the Herbal Pharmacopeia that is less than $1.0 \%$. The small level of ash indicated that only a few material left. The residue included physiological ash, which came from the plant tissue, as well non physiological ash, which constituted residue from foreign material attached to the plant surface, such as sand and soil, so that the lower the ash content is, the smaller residues in the extract. ${ }^{19}$

\section{Heme Polymerization Inhibitory Activity Assay}

Antimalarial examination was performed in vitro by heme polymerization inhibition method. This method is easy and accurate to calculate the ability of a test material as antimalarial agent. The mechanism occurring in the inhibition activity of heme polymerization is the interaction between the test compound and the electrolyte system of heme and or the bond between hydroxyl groups from the test material with heme irons. ${ }^{20}$

Naturally, the plasmodium invades host redblood cell (RBC), and in the RBC, plasmodium parasites will break down hemoglobin to become free heme and amino acids that are the source of parasite cells generation. Site product is free heme which is very toxic for the parasites or the host. ${ }^{21}$ To prevent this, the parasite will transform free heme to be untoxic hemozoin or the typical pigmen of malaria through polymerization. The use of hematin in this study is because hematin changes into $\beta$-hematin which is analog synthetic compound of hemozoin. ${ }^{19}$ The addition of glacial acetic acid is to obtain the acidity level of the vacuole of food parasites at $\mathrm{pH} 5$ as found in its natural condition. ${ }^{22}$ The washing process using DMSO solution is intended to eliminate the remnants of hematin which mixed with unsoluble $\beta$-hematin crystal in DMSO solution. ${ }^{20}$

The percentage of heme polymerization inhibitory activity of suruhan leaves ethanol extract in the same concentration is higher compared to sulphate chloroquine. Suruhan leaves extract also has smaller $\mathrm{IC}_{50}$ of heme polymerization inhibitory compared to $\mathrm{IC}_{50}$ of sulphate chloroquine, which is $0.93 \mathrm{mg} / \mathrm{mL}$, which means that suruhan leaves extract has higher activity to inhibit heme polymerization. The potential of inhibiting hem polymerization of ethanol extract of leaves is better when compared to ethanol extract of Blumea balcamifera in a study conducted by Septiana, et al. ${ }^{23}$ The higher activity may be due to the flavonoid content 
in the ethanol extract of suruhan leaves. The highest flavonoids compounds found in suruhan is peperomin and quercetin. ${ }^{24}$ Peperomin and quercetin are flavonoid of C-4 methoxy derivates. This result is in accordance with the research by Lim et al, which stated that flavonoid of C-4 methoxy derivates has antimalarial potency by inhibiting the mechanism of $P$. falciparum growth until $30-100 \% .{ }^{25}$

\section{Antioxidant Activity Assay}

The antioxidant activity of suruhan leaves extract is due to its flavonoid content. Peperomin and quercetin in suruhan leaves extract has structure that allows flavonoid scavenging activity of free radicals that is the presence of 3,4-dihidroxyl, e.g. dihydroxyl (catechol structure) in $\mathrm{B}$ ring, which acted as electron donor and radical target. 3-OH structure from C-ring is also beneficial for flavonoid antioxidant activity. The double bond conjugation at $\mathrm{C} 2-$ C3 with 4-keto groups, has a role for electron delocalization from B-ring, increasing radical scavenging activity. The presence of 3-OH and $5-\mathrm{OH}$ groups combined with 4-carbonyl function and $\mathrm{C} 2-\mathrm{C} 3$ double bond increase radical activity. In the absence of o-dihydroxy structure at B-ring, hydroxyl subtituent in ring A can be compensated and thus increases antiradical activity ability of flavonoid. ${ }^{26}$

Malaria infection is closely related to the weakening of the host's immune system resulting in the increase of free radicals in the body. This is because the occurring infection decreases antioxidant enzyme and other antioxidant agents that are naturally generated by the body as body natural mechanism to maintain cell equilibrium. Free radicals affect signal transduction at cell and act as iron compounds carrier needed by the parasites to survive in the host's cells. Iron compound is an essential nutrition for the survival and multiplication of Plasmodium cells. Plasmodium parasites digest hemoglobin and produce free heme. Free heme triggers ROS formation which affects malaria pathophysiology. ${ }^{27}$ Therefore, antioxidant ability to bind iron required by the parasites affects parasites survival in host cells. Antioxidants work as reducing agents that give electrons to free radicals so that the free radicals will be inactive or stable before attacking the cells further. ${ }^{28}$ Suruhan leaves extract has linier activity between heme polymerization inhibition and antioxidant, therefore the extract has a great potential to be developed as a source of new antimalarial drug.

\section{CONCLUSION}

The $\mathrm{IC}_{50}$ value of inhibition activity of heme polymerization of ethanol extract of the suruhan leaves is smaller than chloroquine. The strength of ethanol extract of suruhan leaves can be classified as active antioxidant. Ethanol extract of suruhan leaves has great potential as an antimalarial drug and antioxidant.

\section{SUGGESTION}

It is necessary to develop research using fractions and isolates obtained from suruhan leaves. Activity study can be increased by in vivo test using animal models.

\section{ACKNOWLEDGEMENT}

The author would like to thank Uud Nourma from Center for Biomedical and Basic Technology of Health and Pharmacy Department Jenderal Soedirman University for support this research.

\section{REFERENCES}

1. World Health Organization. World Malaria Report 2016. Geneva, Switzerland, 2016.

2. Satyagraha AW, Sadhewa A, Elvira R, Elyazar I, Feriandika D, Antonjaya U, Oyong D, Subekti D, Rozi IE, Domingo GJ, Harahap AR. Assessment of point-of-care diagnostics for G6PD deficiency in malaria endemic rural eastern Indonesia. PLoS neglected tropical diseases. 2016 Feb 19;10(2):e0004457.

3. Huy NT, Uyen DT, Maeda A, Trang DTX, Oida T, Harada S, et al.Simple colorimetric inhibition assay of heme crystallization for high-throughput screening of antimalarial compounds. Antimicrobial Agents Chemother. 2007;51(1):350-3.

4. Cruz AM, DeJong RJ, Charles B, Gupta L, Kumar S, Gutierrez GJ, et.al. Reactive Oxygen Species Modulate Anopheles gambiae Immunity against Bacteria and Plasmodium. The Journal Of Biological Chemistry. 2008;283(6):3217-3. 
5. Valko M, Leibfritz D, Moncol J, Cronin M, Mazur M, Telser JC. Free radicals and antioxidants in normal physiological functions and human disease. International Journal of Biochemistry and Cell Biology. 2007;39(1):44-84.

6. O'Neill PM, Barton VE, Ward SA, The Molecular Mechanism of Action of Artemisinin-The Debate Continues. Molecules. 2010;15(3):1705-21.

7. Kumar A, Kaur R, Arora S. Free radical scavenging potential of some Indian medicinal plants. Journal of Medicinal Plant Research. 2010; 4(19):2034-42.

8. Radulovic N, Stankov-Jovanovic V, Stojanovic G, Smelcerovic A, Spiteller M, Asakawa Y. Screening of in vitro antimicrobial and antioxidant activity of nine Hypericum species from the Balkans. Food Chemestry. 2007;103(1):15-21.

9. Roby MHH, Sarhan MA, Selim KAH. Khalel KI. Evaluation of antioxidant activity, total phenols and phenolic compounds in thyme (Thymus vulgaris L.), sage (Salvia officinalis L.), and marjoram (Origanum majorana L.) extracts. Industrial Crops and Products, 2013, 43: 827-31.

10. Wiart C. Medicinal plants of Asia and the Pacific. 2006. CRC Press, Florida, USA

11. Kartika IG, Insanu M, Safitri D, Putri CA, Adnyana IK. New update: traditional uses, phytochemical, pharmacological and toxicity review of Peperomia pellucida (L.) Kunth. Phamacology Online Newsletter. 2016;2:3043

12. Angelina M, Amelia P, Irsyad M, Meilawati L, Hanafi M. Karakterisasi ekstrak etanol herba katumpangan air (Peperomia pellucida L. Kunth). Biopropal Industri. 2015; 6(2):5361.

13. Departemen Kesehatan Republik Indonesia. Farmakope Herbal Indonesia, Edisi I. Jakarta, 2008.

14. Daskum AM. In vitro investigation into the Haemin Polymerization Inhibitory activity of chloroquine and emetine dihydrochloride hydrate. Journal of Malaria Research and Reviews. 2016; 4(1):7-18.

15. Guetzoyan L, Yu X, Ramiandrasoa F, Pethe S, Rogier, C, Pradines B, et.al. Antimalarial acridines: Synthesis, in vitro activity against P. falciparum and interaction with hematin Bioorganic \& Medicinal Chemistry. 2009; 17(23):8032-9.

16. Yunarto N, Aini N. Effect of purified gambir leaves extract to prevent atherosclerosis in rats. Health Science Journal of Indonesia. 2015; 6(2):105-10.

17. Babu D, Gurumurthy P, Borra SK, Cherian KM. Antioxidant and free radical scavenging activity of triphala determined by using different in vitro models. Journal of Medicinal Plants Research. 2013;7(39): 2898-905

18. Irsyad M. Standarisasi Ekstrak Etanol Peperomia pellucida (L) Kunth. Thesis. Universitas Islam Negeri Syarif Hidayatullah. Jakarta, 2013.

19. WHO. Quality control methods for herbal materials. 2nd Edition. World Health Organization. Geneva, 2011.

20. Egan TJ. Haemozoin formation. Molecular and biochemical parasitology. 2008 Feb 29;157(2):127-36.

21. Ke H, Sigala PA, Miura K, Morrisey JM, Mather MW, Henderson JP, et al. The heme biosynthesis pathway is essential for Plasmodium falciparum development in mosquito stage but not in blood stages. Journal of Biological Chemistry. 2014;289(50):34827-37.

22. Wahyono, Pudjiono, Widyati P. Uji aktivitas senyawa antiplasmodium dari fungi endofit tanaman Artemisia annua L. Majalah Farmasi Indonesia. 2010;21(4):230-5.

23. Septiana E, Umaroh A, Gangga E, Simanjuntak P. Aktivitas penghambatan polimerisasi heme ekstrak daun sembung (Blumea balsamifera) sebagai antimalaria. Buletin Penelitian Tanaman Rempah dan Obat. 2017 June;28(1):29-36

24. Xu S, Li N, Ning MM, Zhou CH, Yang QR, Wang MW. Bioactive compounds from Peperomia pellucida. Journal of Natural Products. 2006 Feb 24;69(2):247-50.

25. Lim SS, Kim H, Lee D. In vitro antimalarial activity of flavonoids and chalcones. Bulletin-Korean Chemical Society. 2007 Dec 20;28(12):2495.

26. Brunetti C, Di Ferdinando M , Fini A, Pollastri S, Tattini M. Flavonoids as 
antioxidants and developmental regulators: relative significance in plants and humans. International Journal of Molecular Sciences. 2013; 14: 3540-55.

27. Gopalakrishnan AM, Kumar N. Antimalarial action of artesunate involves DNA damage mediated by reactive oxygen species.
Antimicrobial Agents Chemotherapy. 2015;59(1):317-25.

28. Percario S, Moreira DR, Gomes BAQ, Ferreira MES, Goncalves ACM, Laurindo PSOC, et al. Oxidative stress in malaria International Journal of Molecular Sciences. 2012;13(12):16346-72. 